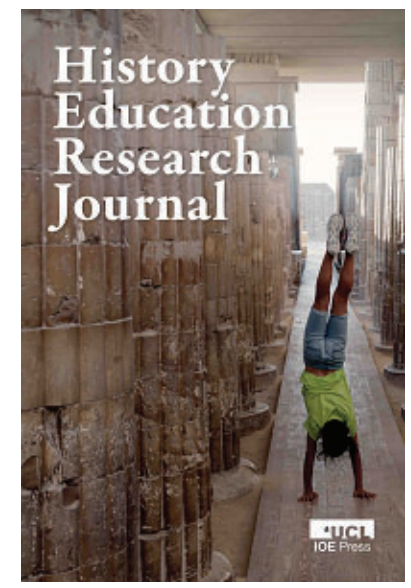

HISTORY EDUCATION RESEARCH JOURNAL

ISSN: 2631-9713 (Online)

Journal homepage:

https://www.ingentaconnect.com/content/ioep/herj

\title{
Digital learning in European history education: Political visions, the logics of schools and teaching practices
}

Maren Tribukait

\section{How to cite this article}

Tribukait, M. (2020) 'Digital learning in European history education: Political visions, the logics of schools and teaching practices'. History Education Research Journal, 17 (1), 4-20. DOI https://doi.org/10.18546/HERJ.17.1.02

Submission date: 2 May 2019

Acceptance date: 11 November 2019

Publication date: 1 April 2020

\section{Peer review}

This article has been peer reviewed through the journal's standard double-blind peer review, where both the reviewers and authors are anonymized during review.

\section{Copyright}

(C) Copyright 2020 Tribukait. This is an Open Access article distributed under the terms of the Creative Commons Attribution Licence (CC BY) 4.0 https://creativecommons.org/licenses/by/4.0/, which permits unrestricted use, distribution and reproduction in any medium, provided the original author and source are credited.

\section{Open access}

The History Education Research Journal is a peer-reviewed open-access journal. 


\title{
Digital learning in European history education: Political visions, the logics of schools and teaching practices
}

\author{
Maren Tribukait* - Georg Eckert Institute for International Textbook Research, \\ Germany
}

\begin{abstract}
The advancement of digital technology has raised hopes of radical improvements in education, such as a new culture of learning. History educators have underlined that the use of digital media could help students to develop a constructivist understanding of history while at the same time rendering history more vivid, relevant and exciting. The last twenty years have shown, however, that even though digital media are increasingly being used in schools, there have been no significant changes in European education systems. This paper helps explain the gap between expectations and reality by exploring how contemporary education policies and curricula in the EU and at the national level frame digital learning in schools and history education. It shows that the ambitious vision of digital learning included in EU policies is closely related to the EU's knowledge economy goals, to which national governments, however, do not fully subscribe. These national policies emphasize the wider role of education in society, which includes strengthening social cohesion and incorporating humane, democratic and civic values. They also take into account the relative autonomy of schools, whose own institutional logics eventually decide how ideas take shape in everyday teaching practice. The relative autonomy of schools is reflected by history curricula that do not include substantial requirements, but only a few optional suggestions concerning the use of digital media. Practitioners' experiences and empirical research indicate that the suggested uses can be part of effective student-centred teaching approaches, but demand considerable investments of time, resources, efforts and creativity. The discussion of these examples also illustrates that the economistic EU vision of digital learning is not a suitable framework for the key concerns of history education. A revised vision of digital learning could and should, therefore, include other important education aims, such as democratic values, social cohesion and active citizenship.
\end{abstract}

Keywords: digital learning; digital competence; digital technology; education policy; European Union; history curricula

\section{Introduction}

The advancement of digital technology has raised hopes of radical improvements in education. These hopes have been inspired by the features of digital technology - its interactivity, multimediality, storage capacity, ubiquitous accessibility and network character. While there are many ideas in circulation regarding how best to use digital technologies in education, the concept of a new culture of learning has gained prominence, referring to constructivist models of individualized, self-directed, 
immersive explorations on the internet or in other digital media (Hesse, 2004; Thomas and Brown, 2011). Two related concepts have emerged with the rise of Web 2.0: connected learning and participatory learning, which are modelled on informal online learning practices and stress the collaborative nature of learning with digital media (Jenkins et al., 2006; Davidson and Goldberg, 2010: 5; Ito et al., 2013: 4-9).

These general approaches have also helped spark ideas about how to improve history education in schools using digital media. The idea of enhancing learner-centred pedagogies with digital media has proved particularly inspiring for history educators when combined with subject-specific considerations. The following uses of digital technologies are deemed to support specific aspects of historical thinking (see Körber, 2008; Bernsen et al., 2012; Kelly, 2013; Haydn, 2013; Pallaske, 2015; Demantowsky, 2015). It is, for example, assumed that:

- easy access to vast source collections could facilitate students' perception and understanding of multiple perspectives

- creating historical narratives with digital media could help students reflect on the multiple ways in which history is constructed

- digital tools will enable exchange and collaboration with other learning groups, experts or witnesses outside the classroom, which will expose students to differing views and the controversial nature of history

- access to public debates and to memory culture on the internet could make it easier for students to link the past to the present and to understand forms of remembrance

- social media could enable students to participate in public debates about historical issues.

All these uses, which may, in practice, support more than one aspect of historical thinking, are seen as considerable steps towards innovative forms of history education that overcome some pitfalls of conventional teaching, such as students' belief in the authority of the textbook, their uncritical reproduction of the master narrative, the difficulties of seeing the relevance of historical issues and the monotony of teacherand text-centred lessons (Fichten, 1993; Von Borries, 1995; Von Borries et al., 2005; Ahlrichs and Macgilchrist, 2017; Breidenstein, 2006). Ultimately, these uses pursue the challenging long-term goal of teaching students a constructivist understanding of history with which they often struggle (Martens, 2010), while simultaneously rendering history more vivid, relevant and exciting.

However, the last twenty years have shown that even though the use of digital media has increased in schools such radical changes have not taken place on a broader scale, at least not in European education systems (Loveless and Williamson, 2013: 158; Davies and Eynon, 2013: 14; European Commission, 2015: 56-60; Tribukait et al., 2017: 101). Some attribute the gap between expectations and reality to the innate complexities of teaching and learning (Haydn, 2013); others point to the importance of the context surrounding the use of technologies (Brown, 2009) or dispute idealized conceptions of digital technology and its supposed impact on education (Selwyn, 2014).

While the above arguments are convincing, it is also possible that education policies do not sufficiently support the use of digital media in schools, not only in terms of the provision of technical equipment, infrastructure, training and educational materials, but also in terms of appropriate conceptual frameworks. In order to consider this aspect of the discussion, this paper will explore policies and curricula that shape digital learning in history education. Since, from a governance studies perspective, political power is not wielded solely by the nation state and its bureaucratic organs but by a multitude of local, national and international stakeholders (Leuze et al., 2008; Ball, 
2010; Theobald, 2013: 43; Altrichter, 2015: 16), the paper examines the supranational and the national levels of policymaking: guidelines issued by the European Union (EU) as well as strategy papers and curricula issued by individual European states. Based on a study that was conducted within the Innovative History Education for All project, ${ }^{1}$ the paper asks: (1) how EU education policy conceptualizes and encourages the use of digital technologies in European schools; (2) how national education policies approach the implementation of digital learning in schools; and (3) how national curricula envisage digital technologies being used in history education.

What stands out most from a comparison of the supranational and national levels, conducted in the first and second sections of this paper, is the contrast between the ambitious expectations of digital learning included in EU policies and the frequently hesitant approaches on the national level. This contrast appears to be heightened by the lack of substantial digital learning requirements for history in the curricula, identified in the third section of the paper. This divergence between $\mathrm{EU}$ and national policies can be explained by the influence exerted at the local level of policymaking through schools and their institutional logics, which are difficult to change through policy decisions at superordinate levels (Fend, 2006: 174-5). As texts that are produced by bureaucrats but also influenced by teachers, history curricula reflect these diverging logics of schools. The lack of specific requirements for digital learning could be interpreted as inertia or indifference to innovation in schools, but the gap could also represent inconsistencies between history education aims and digital education concepts put forward at superordinate levels. The third section therefore also takes up some of the possible uses for digital media hinted at in history curricula, discusses in which ways these suggestions might support history education aims in practice, and points to inconsistencies in the vision of digital learning as observed on the micro level. In conclusion, the paper argues that the vague and ambiguous EU vision of digital learning does not provide an appropriate conceptual framework for digital learning within history education in Europe and should be reconsidered in order to inspire innovative student-centred history teaching.

\section{The vision of digital learning in EU education policy}

Since the creation of the EU in 1993, its actions in education policy have been limited to supporting member states in accordance with the principle of subsidiarity while education remained in the policy remit of the member states (Martens and Wolf, 2006: 153). As with other international or supranational organizations, such as the Organisation for Economic Co-operation and Development (OECD), the EU was initially instrumentalized by national governments in order to put pressure on their education systems and enact reforms but has, since the adoption of the Lisbon Strategy in 2000, become a policymaker in its own right (Martens and Wolf, 2006; Leuze et al., 2008: 3; Parreira do Amaral, 2006: 101; Moutsios, 2007: 18). In comparison to national governments, it must be pointed out, however, that the role of these international or supranational organizations is to exert 'non-coercive, "softer" forms of power rather than any direct "hard" influence' (Selwyn, 2013: 50), especially in wealthier countries that are able to retain control of their educational systems due to their position in the international hierarchy.

The starting point of the EU's active education policy was the understanding of education as an important contributor to Europe's knowledge economy goals (Lawn and Grek, 2012: 83). In order to 'become the most competitive and dynamic knowledge-based economy in the world' (European Parliament, 2000) the EU targeted several supposed deficits within European education systems, such as the high 
number of early school leavers, and sought to bring formal education more in line with the demands of the economy. The guiding principle of the competitive knowledge society is based on the assumption that economic growth and competitive advantage are 'a direct outcome of the levels of investment in developing human capital' (Rizvi and Lingard, 2009: 446). This approach promoted an instrumental understanding of education that stressed the importance of technoscientific knowledge, as well as cognitive and vocational skills (Kazamias, 2009: 808-9). It was supported by the conceptual shift from education to learning as a measurable process, and the rise of evidence-based policymaking. In the Lisbon Strategy, quality and efficiency became the core features that mattered most in education policy (Lawn and Grek, 2012: 83-4, 97).

The instrumentalist approach to education included an appreciation of digital technologies. Consequently, the EU assumed the role of an innovation driver in Europe by promoting digital learning, digital competence and open educational resources. One of the EU's first steps was to ambitiously define digital competence as a transversal competence associated with critical thinking, creativity and problem solving, in the reference framework Key Competences for Lifelong Learning issued by the European Parliament and the Council in 2006 (European Parliament and Council of the European Union, 2006). The paper states that all EU citizens should acquire digital competence from their education, in addition to seven other key competences, and continuously refresh them in order to remain adaptable and flexible in the face of the challenges posed by the globalized world. The strategic framework Education and Training 2020 sets the goals for education policy, which conforms with the new Europe 2020 growth strategy resulting from the Lisbon process. This framework confirms this approach by emphasizing the importance of digital technology for lifelong learning and of digital competences to enhance creativity and innovation (Council of the European Union, 2009: 3). The next milestone within this strategic framework was the 2013 European Commission initiative Opening up Education, which aims to stimulate high-quality and innovative forms of teaching and learning with the aid of digital technology and content (European Commission, 2013). It seeks to promote open learning environments in order to improve quality and efficacy in education and to subsequently contribute to the aims of the Europe 2020 growth strategy. The text makes wide-ranging recommendations in these areas on how member states should best link technological, organizational and pedagogic innovation.

The two guidelines, Key Competences for Lifelong Learning and Opening up Education, show how the EU vision of digital learning is shaped by values and agendas that have been positively associated with educational technologies for the last few decades. Among the five sets of values and agendas that Neil Selwyn (2014: 32-5) has identified, two have a prominent place in the policy papers: namely, learner-centred learning and the efficiencies of education.

In Key Competences for Lifelong Learning, digital competence is defined as the 'confident and critical use of information society technology (IST)'; it builds on 'basic skills in ICT [information and communications technology]' including communication and collaboration in digital networks and should furthermore encompass creativity, innovation and a critical and reflexive attitude towards available information (European Parliament and Council of the European Union, 2006: 13, 15-16). Using the keywords 'critical thinking', 'creativity', 'communication' and 'collaboration', known as the four Cs, the definition links digital competence to the twenty-first-century skills put forward by the Partnership for 21st Century Skills (P21), a United States (US) nonprofit organization comprising business representatives, education leaders and policymakers. While the P21 initiative is driven by the conviction that students have 
to be prepared for the demands of the global economy, its theoretical foundation relies on the ideas of John Dewey, among others, and makes use of progressive education ideals that encompass learner-centred learning (P21, 2007: 11). This link to progressive educational thinking allows a degree of scope in the ways in which the four Cs can be interpreted - either in the instrumentalist understanding, illustrated by such statements as 'workers, of course, must employ critical thinking to better serve customers, develop better products, and continuously better themselves within an ever-changing economy' (P21, 2007: 13), or in a fundamental interpretation that goes beyond the reference frameworks and their foundations.

The second guideline, on Opening up Education, also aims to initiate innovative pedagogies, as indicated by the paper's subtitle: 'Innovative teaching and learning for all through new technologies and open educational resources'. Learner-centred learning is framed, however, in a technocratic language of surveillance, and is thus far removed from progressive educational thinking:

Through learning analytics, new and more learner-centred teaching methods can emerge since the evolution of learners who use ICT regularly can be closely monitored: teachers may know the exact learning outcomes of each individual and identify needs for additional support depending on each individual's learning style. (European Commission, 2013: 5)

As shown by this example, the text expresses a set of values predominantly oriented towards organizational effectiveness and the efficiency of education. First, the text emphasizes that education in the EU is not keeping pace with the digital economy and society - in contrast to the US and some Asian countries - and thus classifies education technology as an indicator of economic competitiveness. Second, it underlines that digital technology provides opportunities to simultaneously increase efficiency and equity in education: 'Open technologies allow All individuals to learn, Anywhere, Anytime, through Any device, with the support of Anyone (European Commission, 2013: 3, emphasis in original). A further supposition is that digital technology has the potential to reduce costs for education institutes and their students, particularly those from disadvantaged groups; although on the other hand, the paper demands substantial investments into infrastructure and human resources (ibid.: 5, 10-11).

The two sets of guidelines show that the vision of digital learning is oriented towards the EU's knowledge economy goals and corresponds to common notions of the benefits of educational technology. However, the supposed pedagogical and financial benefits of the use of educational technologies are not outlined in great detail. This vagueness extends to conceptual ambiguities: first, educators leaning towards progressive educational ideals might link critical thinking and creativity to empowerment rather than to employability; second, the alleged financial gains of organizing education with the help of digital technologies are juxtaposed by the high investments demanded for these technologies. Furthermore, efficient learning in the form of closely controlled personalized learning seems to contradict demands for creativity and critical thinking, which encompass a degree of unpredictability and openness in the learning process.

\section{National education policies: Between knowledge economy goals and the relative autonomy of schools}

As shown by the strategy framework Education and Training 2020, European states remain committed to the dual social and economic function of education for the 
individual and for society as a whole. In the text, the member states agree on the importance of 'personal, social and professional fulfilment of all citizens' and 'sustainable economic prosperity and employability', as well as the promotion of 'democratic values, social cohesion, active citizenship, and intercultural dialogue' as education aims (Council of the European Union, 2009: 3), thereby confirming the approach taken in the Key Competences for Lifelong Learning (European Parliament and Council of the European Union, 2006: 13). Critics of the Lisbon process have reproached the EU for merely paying lip service to democratic, social and civic values for the benefit of economic goals (Kazamias, 2009: 809). The economistic approach to education in EU policy was outlined in the previous section, but it is also important to pay attention to differences between the declarations from the European Commission and those from the Council of the EU.

On the one hand, in the European Commission initiative Rethinking Education, which was launched in 2012, the education aims of active citizenship, personal development and well-being are explicitly given lower priority than, and are seen as subordinate to, the demands of the economy (European Commission, 2012: 2). On the other hand, the revisions by the Council to the Education and Training 2020 strategy in 2015 showed a slight shift towards the social role of education, which came against the backdrop of the terrorist attacks in France and the refugee crisis. The text shows an increasing focus on the role of education in perpetuating humane and civic values and imparting such values to the next generation. It underlines that education can create an environment that fosters freedom of opinion, social cohesion and mutual respect, and that impedes and combats discrimination (Council of the European Union, 2015: 2-3). These new priorities suggest that member states, as represented through the Council, were more sensitive to the broader role of education in society than the European Commission, and were reluctant to reduce education aims to economic growth and employability.

When scrutinizing the education policies of European states that focus on digital strategies, it becomes clear that the EU vision of digital learning has not yet trickled down to all European education systems. In terms of strategies for digital learning in schools, there are great differences between individual European countries in respect to implementation, scope and effectiveness (Tribukait et al., 2017: 101). At one end of the scale is, for example, Denmark. Defining itself as a democratic and digital knowledge society, it implemented the teaching of digital competences from primary school onwards in 2009 in order to enable citizens to fully participate in a society oriented towards global competition (Moos and Kofod, 2012: 64). It chose an integrated approach that included the definition of digital education aims, curriculum adaptations, the improvement of technical infrastructure, the development of learning resources, the qualification of teachers and the implementation of research programmes (Tribukait et al., 2017: 44). These measures seem to have had a positive effect on the digital competences of 15-year-old students, whose test scores were above average in the International Computer and Information Literacy Study in 2013 (Fraillon et al., 2014: 96). However, in spite of these efforts, evaluation studies revealed a lack of new teaching approaches in practice; the results therefore remained below expectations in this area (Danmarks Evalueringsinstitut, 2015: 10-12).

In other countries, such as Germany, education ministries have only just begun to adapt their policies and curricula to the digital age (Tribukait et al., 2017: 56). A strategy paper called 'Education in the digital world' (Bildung in der digitalen Welt) adopted by all 16 German states argues that digital change affects all aspects of life and offers opportunities as well as challenges, but does not refer explicitly to the 
knowledge society paradigm (KMK, 2016: 8). It aims at the implementation of relevant 'competences for the digital world' in the curricula and the systematic use of digital technologies in classrooms from primary school onwards (ibid.: 11-12). However, substantial investments in technical infrastructure and equipment, learning resources or teacher qualification had not taken place before the 'DigitalPakt Schule' was agreed in 2019. Consequently, the availability of digital equipment was below that of most other EU states and students' test scores in the Information and Computer Literacy Study in 2013 were average (Tribukait et al., 2017: 55; Eickelmann et al., 2014: 16-17).

Given the different levels of commitment to digital education and varying degrees of alignment with knowledge society rhetoric (for Denmark, see Moos and Kofod, 2012: 69) - it is remarkable that both German and Danish education policy guidelines emphasize the primacy of pedagogy over technology (Tribukait et al., 2017: 36, 39; KMK, 2016: 7). This points to the relative autonomy of schools in modern states, which governments must take into account when designing their policies. If we view schools, from a functionalist perspective, as institutions that contribute to the reproduction and modernization of society through the integration of individuals into the political system, and their qualification for the job market, as well as their allocation into the socioeconomic system (Fend, 1980, 2006), then it is important to consider that, first, these functions are only translated into explicit policy goals to a certain extent, and second, that there are no straightforward policies to attain these goals (Fend, 2006: 174-5). The difficulty of education governance can be explained by the relative autonomy of the education system as a subsystem of society, which follows an independent pedagogic logic while being embedded in the social structure and bound by policies (Bourdieu and Passeron, 1971: 191-2). Schools as organizations, as well as teachers and students as individuals, act according to this relative autonomy and cannot easily be directed by the logics of other subsystems, such as economics or politics (Bourdieu and Passeron, 1971: 191-2; Adick, 2002: 224; Lang-Wojtasik, 2008: 133, 163-4). In other words, if digital education strategies were imposed upon schools regardless of their pedagogic logics, the chances of success would be low because teachers would be unable to relate to them and would most likely be able to circumvent them. Since the EU vision of digital learning is based mainly on economic goals and only vaguely substantiated in terms of pedagogy, its implementation within the school framework depends on its intelligibility to decision-makers within schools. From the perspective of school logics, it is not sufficient to claim that the use of digital technologies may give students a competitive advantage in the global economy. Their use must also support general education aims, subject-specific teaching and wider pedagogic purposes.

\section{Intersections and inconsistencies between history curricula and the vision of digital learning}

In order to implement digital learning in schools, national governments make use of a classic instrument of education governance: the curriculum. There is a Europeanwide trend towards defining digital competence as a transversal competence, and its transformation into curricular content for secondary education often comes with long lists of general requirements. These regularly include the areas of information research; analysis, interpretation and evaluation of information and media; production of media; collaboration and knowledge-sharing; and presentation and communication (Tribukait et al., 2017: 102-3). In contrast to these diverse aspects of digital competence, however, history curricula for secondary education do not provide a coherent vision of digital learning, but only a few hints relating to how, when and in which contexts these general 
requirements should or could be implemented. By referring the implementation of these general requirements for history teaching to teachers and schools, governments respect a degree of school autonomy, but also leave the implementation of digital learning to chance.

Before taking a closer look at the intersections and inconsistencies of history education and the visions of digital learning, we look briefly at the key principles of history education that feature in the curricula. The history curricula of all seven European states (Albania, Denmark, Germany, Greece, the Netherlands, Poland and Spain) that were examined in regard to digital learning requirements within the Innovative History Education for All project (see Endnote 1) are committed to a critical approach (Tribukait et al., 2017: 102) and oriented towards prominent concepts of history education, in particular historical consciousness (Rüsen, 2008) and historical thinking (Wineburg, 2001; Körber et al., 2007; Seixas and Morton, 2013). The respective curricular documents aim to foster a reflexive historical consciousness (in Albania, Denmark, Germany, Greece, the Netherlands, Poland and Spain; Tribukait et al., 2017: $26,37,51-2,69,77,91$ ), point to multiple interpretations of history (for example, in Germany and Denmark; ibid.: 38, 51-2) or the plurality of memory (for example, in Spain; ibid.: 91), and sometimes aim to encourage students to personally engage in their societies (for example, in the Netherlands; ibid.: 67). The critical reading of sources is highlighted as a key subject-specific method in all these curricula. In this context, the research and critical use of information and materials on the internet are often mentioned as learning goals (for example, in Albania, Denmark, Germany and Spain; ibid.: 26-7, 39, 51, 53, 91, 94).

At first glance, these key principles overlap with the EU definition of digital competence, which includes critical thinking. However, the interpretation of what critical thinking is diverges, in the context of history education, from the instrumentalist approach displayed in EU education policy papers. History education in democracies is understood by a number of scholars as a place where authorities, structures and discourses can be questioned, where dissent can be articulated and where personal experience can be related to public debate (Husbands, 1996: 134; Barton and Levstik, 2004). These critical activities, which do not connect to knowledge economy goals, are also alluded to in the examined history curricula - for example, in the history curriculum for upper secondary education in Lower Saxony:

By addressing past events and structures from a number of different perspectives and tracing them back to the conditions that lead to their creation, and their effects, history teaching clearly outlines the possibilities and limitations of human behaviour and references alternative courses of action that were not taken in the past. Students consequently gain insights into fundamental anthropological constants, for example, and historical structures such as how conflicts evolve and are solved, interaction and association with others, the legitimation of sovereignty, determinants of responsibility and blame as well as historical or political alternatives. This will enable them to confront and deal with differing images of humanity and views of the world. ${ }^{2}$ (Niedersächsische Kultusministerium, 2011: 7)

As points of reference for history teachers, the academic discourse and curricular statements such as those above indicate the scope of how critical thinking can be interpreted.

The inconsistency between the EU vision of digital learning and the aims of history education appears more pronounced when the aspect of efficiency is considered. Even 
though the sensible use of digital technologies might help to create more effective history lessons, these efficiency arguments in support of educational technology seem to work, in the long run, against the key concerns of history education outlined in the previous two paragraphs (see, for example, Rüsen, 2008; Körber et al., 2007; Van Drie and Van Boxtel, 2008; Wineburg, 2001; Husbands, 1996). A video game that is set in the past, such as Civilization III, might provide students with an impression of past societies in a more efficient way than written source material, but students also need to analyse it in order to understand how such a game is constructed, which sources it is based upon and what interpretation of the past it conveys (Kubetzky, 2010). Since the standards of history education remain the same (Demantowsky, 2015: 157-8), digital technology can make history lessons more exciting, but its use does not make learning less complicated in comparison to studying texts. The careful questioning of sources, the analysis of historical narratives and representations, informed argumentations and fact-based debates all require intellectual application that can hardly be measured by efficiency standards and that go beyond an instrumentalist understanding of education.

Consequently, it is important to carefully reflect upon the role of digital technology in history education. If history education aims are not compatible with knowledge economy goals, how can digital technology be implemented in support of critical historical thinking? The uses mentioned in the introduction suggest that learnercentred learning is worth adopting and developing further with the help of digital media, but it needs to be adapted to history education in schools. While the history curricula examined for this study do not give many clues about how digital media could be used, they do contain a few hints (Tribukait et al., 2017: 104). The following three uses are recommended in some European history curricula - and, as pointed out in the introduction, also by history educationists - and can be part of student-centred approaches. The question is how they can support history education in practice and whether teaching experiences confirm the expectations connected to them.

(1) Using the internet to access a wide range of original sources and multiple interpretations in order to strengthen multiperspectivity

As with many other European history curricula, the recommendations that accompany the Danish history curriculum for the upper secondary level celebrate the internet as a great gift to history teaching, and one that offers a virtually unlimited amount of information in the most diverse forms (Ministeriet for børn undervisning og liegestilling, 2010: 17). History educationists such as T. Mills Kelly have also highlighted the shift from a 'pedagogy of scarcity' to an 'unheard of historical abundance' (Kelly, 2013: 26-7). The advantages for history teachers in having access to more source material are evident; they can, for example, present wide-ranging resources in the classroom that may confront students' preconceptions (Haydn, 2013: 14), or they can supplement the textbook with alternative points of view. Non-governmental organizations often provide materials offering historical perspectives of marginalized people that may not be represented in textbooks, such as the transnational initiative Wings and Roots, based in New York and Berlin, which produces pedagogical resources on migration, belonging and racism as part of the Reimagine Belonging project (https://reimaginebelonging.de/).

But research has also shown that students using the internet on their own to search for materials for history tasks rarely make use of the variety of materials and do not actively search for diverging positions or perspectives (Kelly, 2013: 28; Tribukait, 2018), their activities can often be labelled as the 'Google-copy-paste-syndrome' (Hodel, 2013: 16). To turn the abundance of sources into enhanced multiperspectivity, 
it appears necessary for teachers to guide students, either to show them how to search more specifically on the internet or for the teachers to preselect resources for a task. An early concept of digital learning that tackled the challenge of scaffolding studentcentred learning on the internet is WebQuests, developed by Bernie Dodge (1997). A website presents enquiry-based tasks that ideally link an authentic problem to sources on the internet and guide students with questions that aim to encourage higherorder thinking (Blasszauer, 2013; Kerber, 2015; Spahn, 2017). It may address multiple perspectives on a historical topic, such as the WebQuest on the fall of the Berlin Wall, 'Ein Versprecher, der zur Einheit führte?' [Was German unity the result of a slip of the tongue?] by Britta Wehen (http://wizard.webquests.ch/mauerfall89.html?page=39808). If WebQuests suit the skills and interests of a learning group, they can be a good means to engage students either individually or in groups and motivate them to develop a deeper understanding of a problem (Blasszauer, 2013), in a similar way to voluntary practices of connected learning where learners follow a personal interest of their own (Ito et al., 2013). Advanced students who are familiar with the format may even be able to create a WebQuest themselves, as suggested by the history curriculum of Lower Saxony for the upper secondary levels (Niedersächsisches Kultusministerium, 2011: 35).

It takes time for a teacher to design a WebQuest that complies with these high education standards (Blasszauer, 2013: 172). Unfortunately, not all WebQuests shared on the internet meet these standards, and the format may sometimes look rather outdated when compared to Web 2.0 technology (Kerber, 2015: 91; Spahn, 2017: 360). However, the main idea of combining a constructivist approach to learning with the practical knowledge that most students need support to become independent learners is still convincing. Whether with the help of WebQuests, other digital tools or face-toface communication, it is crucial to note that, when dealing with multiple perspectives, teachers need to support and challenge students in order for them to develop higherorder thinking. Such thinking is unlikely to be achieved through the superficial working routines that are often found in compulsory schooling (Breidenstein, 2006: 261).

(2) Creating stories about the past in order to make students understand how historical narratives are constructed

The Danish history curriculum for upper secondary level expects students to express their historical understanding through a range of oral and written formats, with the option to also use digital formats such as podcasts, blogs, websites or documentaries (Ministeriet for børn undervisning og liegestilling, 2010: 7). Similarly, the history curriculum for upper secondary level in Lower Saxony encourages students to create websites, and to conceive games or other digital formats in the optional module 'Encountering history in film and new media' (Niedersächsisches Kultusministerium, 2011: 35). Such tasks take young people's media practices into consideration and often arouse their curiosity and motivate them, which can lead to better historical understanding (Lyndon, 2013: 82). Bernsen et al. (2012: 12) have underlined that creating a podcast, wiki or video about a historical topic is a way for students to understand that historical narratives are constructed. This assumption has so far not been subject to empirical research (Kühberger, 2015: 47), but it is supported by practitioners' experiences. When collaboratively writing in Etherpads, wikis or blogs, students can experience how stories on a historical topic are told from different angles and are open to change (Pallaske, 2017: 305; Marzinka, 2015: 102; for documentaries, see Jones-Nerzic, 2013: 88).

This is also illustrated by feedback from upper secondary level students from a grammar school in Hamburg who participated in a project week at the Neuengamme 
concentration camp memorial in 2011. They researched several topics related to the history of the concentration camp, such as survivors, perpetrators or daily life, and documented their results in a blog (https://ewgprojektblog.wordpress.com/). Two participants explained how they found writing stories with their own voices: 'Blogging was different than expected, because we were given hardly any rules, and we could write what we wanted, which we liked because we had to work independently'. ${ }^{3}$ Two other participants mentioned that their initial reservations faded when they tried the alternative learning approach:

Our first reaction to the prospect of working on the topic was also: 'Oh no, not again!' But on the very first day of the project week we were already really interested. We thought it was good to be in the place where these events had taken place, to better understand what happened there. Compared to just sitting in school learning dully from the book. We also thought the mixture of listening, independent reading and writing our own texts worked well. It is a great, creative idea to document everything in a blog and make it accessible for everybody. And what's even better is that it's an open-ended process ... ${ }^{4}$

The students' last remark demonstrates the insight gained through the experience that history is an open process, which contrasts with the authoritative presentation of history in textbooks.

As far as one can tell from teachers' and students' experiences, using digital tools to produce stories about the past is a rewarding student-centred task that supports important history education aims that are difficult to attain through conventional approaches alone. It has to be noted, however, that the positive learning experiences of the quoted students were not only the result of using digital media, but they were also enhanced by the special setting of a project week outside school at a concentration camp memorial, which was supported by a team that included their history teacher, a memorial expert and a media adviser. As such, they obviously involved a great deal more preparation than a normal history lesson. This is also confirmed by authors who have shared experiences of storytelling in other formats such as documentary film, which requires the teacher to familiarize himself or herself with video-cutting technology before being able to start, for example (Jones-Nerzic, 2013: 89).

(3) Analysing examples of contemporary history or memory culture in digital media, such as feature films, YouTube clips or computer games, in order to help students understand how the past is publicly presented and debated

German and Danish history curricula require students to analyse and deconstruct examples of history culture in different kinds of media, such as feature films, documentaries, video games and websites, and to understand the functions and intentions of public forms of remembrance (Thüringer Ministerium für Bildung, Wissenschaft und Kultur, 2011: 42; Niedersächsische Kultusministerium, 2011: 35; Undervisningsministeriet, 2013). It has also been highlighted by history educationists that examples of history culture on the internet must be analysed in the same way as any other source with respect to the intentions of the authors and the media format, which can help to effectively bring home the message that there is no single correct account of past events, and that different and controversial points of view exist (Körber, 2008; Demantowsky, 2015). The possibility of more easily linking the past to the present due to the digital transformation of the public sphere offers history teachers the advantage of showing the relevance of topics (Haydn, 2013: 18); at the same time, this is also imperative if they 
want to relate their teaching to contemporary societal developments. By exploring debates, for example about the renaming of streets in Berlin's Afrikanischen Viertel on the Facebook page of the Berlin Postkolonial initiative and in online newspaper articles, students could see that the interpretation of colonialism is still controversial and is actively negotiated by citizens (www.facebook.com/berlinpostkolonial/).

Some history educationists therefore go further than the quoted curricula by pointing out that students should not only receive and understand the information, but should also be prepared to participate as citizens in digital history culture. In addition to analysing examples of history culture, students should therefore be taught how to participate in online debates (Kühberger, 2015). Teaching experiences of student groups discussing issues in closed discussion forums have been evaluated positively (ibid.:15; Chapman, 2013), but there has not yet been any empirical research conducted into the extent to which students could benefit from participation in online public debates about the past.

These three uses of digital technology could help develop historical thinking skills while also stimulating critical engagement with digital technology, which extends, however - as the discussion of the examples has shown - beyond the understanding displayed in EU education policy papers. Teachers' and students' experiences indicate that these uses may be more effective in inspiring a deeper understanding of history than traditional textbook-based teaching, especially when they are embedded in student-centred approaches, but success can depend on many factors, such as the teacher's scaffolding skills, a learning site outside school or support from external experts. Furthermore, since historical learning involves complex cognitive operations as well as affective aspects (for example, Barton and Levstik, 2004), it is difficult to measure learning results (Seixas and Ercikan, 2015: 4) and make direct connections between input and output as demanded by evidence-based policymaking. This might also explain why these promising approaches, the success of which is not proven, are only mentioned marginally in history curricula as options, if at all.

The experiences of digital learning discussed above also confirm that, in contrast to the vision of EU education policy, technology does not make history education more efficient for teachers or for students in terms of a cost-benefit ratio, since it creates new tasks that demand more preparation by teachers and as much intellectual curiosity and critical faculty from students as traditional ways of studying history. On a positive note, learning with digital media in the ways described has the potential to motivate and engage students more than usual, so that learning might not 'feel' as strenuous as in conventional history lessons.

\section{Conclusion}

A critical examination of European education policies and history curricula has offered some insights that help explain the gap between expectations and reality in terms of digital learning. It has shown that there is a vision of digital learning at EU level, but no definite conception of how this vision could be successfully implemented. One reason for this is the vagueness of the vision, especially in terms of pedagogies. It refers mainly to two sets of values, learner-centred learning and the efficiencies of education, which are ambiguous, if not, in part, contradictory. Another reason is the 'soft' character of EU education policy, to which national governments are not tightly bound. This leads to the third and decisive reason: in their education policies, national governments are not fully committed to the knowledge economy goals in which the vision of digital learning is embedded. Respective education policies generally 
emphasize the wider role of education in society, which includes strengthening social cohesion and incorporating humane, democratic and civic values. They also take into account the relative autonomy of schools, whose internal logics eventually decide how ideas take shape in everyday teaching practice. Educational technology is classified as an indicator of economic competitiveness in EU policy papers, but member states emphasize the primacy of pedagogy over technology. It can therefore be argued that the discourse of 'imperatives of the global economy' (Rizvi and Lingard, 2010: 97) has not yet been fully imposed on school systems in Europe.

In terms of history education, the analysis of policy and curricula suggests that critical thinking represents the point where visions of digital learning and historical thinking intersect. History teaching could therefore strengthen students' digital competence, but the instrumental approach to education is not a suitable framework for the key concerns of history education, which include an understanding of critical thinking that extends beyond knowledge economy goals. Since the subject aims to foster a reflexive historical consciousness, it is far more suited to supporting 'democratic values, social cohesion, active citizenship, and intercultural dialogue' (Council of the European Union, 2009: 3), and thus education aims that could and should also be part of a vision of digital learning in Europe. Furthermore, the vision of learner-centred learning in EU policy papers, which oscillates between close surveillance of students and progressive educational ideals, is too ambivalent to have a significant impact on history curriculum designers on the national level. The EU policy papers seem to ignore the fact that, first, student-centred learning in schools is different from informal self-directed learning, and that, second, student-centred learning around digital media is a challenging and complex task, as demonstrated by empirical research and the experiences of history teachers. While it has the potential to effectively support higher-order historical thinking, perhaps more so than conventional textbook-based teaching, there are no easy ways to attain the desired outcome. That is why the efficiency argument is ultimately misleading. It suggests that the effective use of technology will also save time and costs, but the opposite is the case: large investments of time, resources, efforts and creativity are crucial to successfully design and realize inspiring forms of digital learning in the field of history education. Policymakers should take this into account when making funding decisions concerning the implementation of digital technologies in education - and also when designing conceptual frameworks for digital learning.

\section{Notes}

1 The study analyses education policies concerning the use of digital media in history lessons across Europe. It has been conducted as part of the project Innovative History Education for All (IHEA), co-funded by the ERASMUS+ Programme of the European Union, at the Georg Eckert Institute for International Textbook Research between November 2015 and June 2016. It specifically investigated digital strategies, media education concepts, curricula frameworks and history curricula that together shape the requirements, guidelines and expectations for ICT use in history lessons. In addition to analysing European Union policy, the study includes case studies of seven European countries (Albania, Denmark, Germany, Greece, the Netherlands, Poland and Spain) that were chosen by the criteria of best practice and balanced representation (see Tribukait et al., 2017).

2 The German original reads: 'Indem der Geschichtsunterricht vergangene Ereignisse und Strukturen unter verschiedenen Perspektiven thematisiert und sie auf die Bedingungen ihres Werdens und Wirkens zurückführt, macht er exemplarisch Möglichkeiten und Grenzen menschlichen Handelns deutlich und verweist auch auf in der Vergangenheit nicht realisierte Handlungsalternativen. Dadurch gewinnen Schülerinnen und Schüler z. B. Einsichten in anthropologische Grundkonstanten und historische Strukturen wie die Entstehung und Lösung von Konflikten, den Umgang mit dem Fremden, die Legitimation von Herrschaft, die Bedingungsfaktoren von Schuld und Verantwortung bzw. historische oder politische Handlungsalternativen. Insofern werden sie befähigt, sich mit 
unterschiedlichen Menschenbildern und Weltdeutungen auseinanderzusetzen.' (Translated by Nicola Watson, Georg Eckert Institute.)

3 The German original reads: 'Das Bloggen war ganz anders als erwartet, da es wirklich kaum Regeln gab und man das schreiben konnte, was man wollte-was wir gut fanden, da man so selbstständig arbeiten musste' (https://ewgprojektblog.wordpress.com/feedback-der-projektgruppe/) (translated by the author).

4 The German original reads: 'Auch bei uns bestand die erste Reaktion auf das bevorstehende Thema aus: "Oh nein, nicht schon wieder!" Dies hat sich gleich am ersten Tag der Projektwoche in großes Interesse umgewandelt. Wir fanden es gut direkt an der Quelle des Geschehens zu sein, um dort Geschichte zu verstehen. Anstatt nur stumpf in der Schule aus dem Buch zu lernen. Desweiteren fanden wir die Mischung aus Zuhören, selbstständig Lesen und eigenständiges Verfassen von Texten gelungen. Eine schöne und kreative Idee ist es nun dies alles in einem Blog festzuhalten und für jeden sichtbar zu machen. Und vor allem handelt es sich dabei um einen Prozess der nicht endet ...' (https://ewgprojektblog.wordpress.com/feedback-der-projektgruppe/) (translated by the author).

\section{Acknowledgements}

I would like to thank EuroClio and the Innovative History Education for All project team for the constructive cooperation, Nicola Watson (Georg Eckert Institute) for the linguistic revision, and the ERASMUS+ Programme of the European Union for the funding.

\section{Notes on the contributor}

Maren Tribukait graduated in history from Humboldt University, Berlin. Before obtaining her doctorate from the University of Bielefeld, she worked as an editor for an educational publisher. As a research fellow at the Georg Eckert Institute for International Textbook Research, she specializes in history education and focuses on digital education, media practices in schools and teaching controversial issues in history.

\section{References}

Adick, C. (2002) 'Demanded and feared: Transnational convergencies in national educational systems and their (expectable) effects'. European Educational Research Journal, 1 (2), 214-33.

Ahlrichs, J. and Macgilchrist, F. (2017) 'Medialität im Geschichtsunterricht: Die Rolle des Schulbuchs beim Vollzug von "Geschichte"'. Zeitschrift für interpretative Schul- und Unterrichtsforschung, 6, 14-27.

Altrichter, H. (2015) 'Theory and evidence on governance: Conceptual and empirical strategies of research on governance in education'. In Schrader, J., Schmid, J., Amos, K. and Thiel, A. (eds) Governance von Bildung im Wandel: Interdisziplinäre Zugänge. Wiesbaden: Springer VS, 25-43.

Ball, S.J. (2010) 'New states, new governance and new education policy'. In Apple, M.W., Ball, S.J. and Gandin, L.A. (eds) The Routledge International Handbook of the Sociology of Education. London: Routledge, 155-66.

Barton, K.C. and Levstik, L.S. (2004) Teaching History for the Common Good. Mahwah, NJ: Lawrence Erlbaum Associates.

Bernsen, D., König, A. and Spahn, T. (2012) 'Medien und historisches Lernen: Eine Verhältnisbestimmung und ein Plädoyer für eine digitale Geschichtsdidaktik'. Zeitschrift für digitale Geschichtswissenschaften, 1, 1-27. Online. https://tinyurl.com/vg84x7k (accessed 26 December 2019).

Blasszauer, J. (2013) 'History webquests'. In Haydn, T. (ed.) Using New Technologies to Enhance Teaching and Learning in History. London: Routledge, 171-84.

Breidenstein, G. (2006) Teilnahme am Unterricht: Ethnographische Studien zum Schülerjob. Wiesbaden: VS Verlag für Sozialwissenschaften.

Brown, A. (2009) 'Digital technology and education: Context, pedagogy and social relations'. In Cowen, R. and Kazamias, A.M. (eds) International Handbook of Comparative Education. Dordrecht: Springer, 1159-72. 
Bourdieu, P. and Passeron, J.-C. (1971) Die Illusion der Chancengleichheit: Untersuchungen zur Soziologie des Bildungswesens am Beispiel Frankreichs. Stuttgart: Ernst Klett.

Chapman, A. (2013) 'Using discussion forums to support historical learning'. In Haydn, T. (ed.) Using New Technologies to Enhance Teaching and Learning in History. London: Routledge, 58-72.

Council of the European Union (2009) 'Council conclusions of 12 May 2009 on a strategic framework for European cooperation in education and training ("ET 2020")'. Official Journal of the European Union, C119, 52, 2-10. Online. https://tinyurl.com/yf9jr78o (accessed 6 January 2020).

Council of the European Union (2015) 2015 Joint Report of the Council and the Commission on the Implementation of the Strategic Framework for European Cooperation in Education and Training (ET 2020): New priorities for European cooperation in education and training. Brussels: Council of the European Union. Online. https://tinyurl.com/ygd79g3d (accessed 6 January 2020).

Danmarks Evalueringsinstitut (2015) It på ungdomsuddannelserne: En kortlægning af it som pædagogisk redskab på gymnasier og erhvervsuddannelser. Copenhagen: Danmarks Evalueringsinstitut. Online. https://tinyurl.com/ydpca2tz (accessed 6 January 2020).

Davidson, C.N. and Goldberg, D.T. (2010) The Future of Thinking: Learning institutions in a digital age. Cambridge, MA: MIT Press.

Davies, C. and Eynon, R. (2013) 'Studies of the internet in learning and education: Broadening the disciplinary landscape of research'. In Dutton, W.H. (ed.) The Oxford Handbook of Internet Studies. Oxford: Oxford University Press, 328-49.

Demantowsky, M. (2015) 'Die Geschichtsdidaktik und die digitale Welt: Eine Perspektive auf spezifische Chancen und Probleme'. In Demantowsky, M. and Pallaske, C. (eds) Geschichte lernen im digitalen Wandel. Berlin: De Gruyter Oldenbourg, 149-61.

Dodge, B. (1997) 'Some thoughts about WebQuests'. Online. https://tinyurl.com/yjtn67qv (accessed 6 January 2020).

Eickelmann, B., Gerick, J. and Bos, W. (2014) 'Die Studie ICILS 2013 im Überblick - Zentrale Ergebnisse und Entwicklungsperspektiven'. In Bos, W., Eickelmann, B., Gerick, J., Goldhammer, F., Schaumburg, H., Schwippert, K., Senkbeil, M., Schulz-Zander, R. and Wendt, H. (eds) ICILS 2013: Computer- und informationsbezogene Kompetenzen von Schülerinnen und Schülern in der 8. Jahrgangsstufe im internationalen Vergleich. Münster: Waxmann, 9-31. Online. https://tinyurl.com/s77edwp (accessed 6 January 2020).

European Commission (2012) 'Rethinking education: Investing in skills for better socio-economic outcomes'. Online. https://tinyurl.com/ydj24ets (accessed 6 January 2020).

European Commission (2013) 'Opening up education: Innovative teaching and learning for all through new technologies and open educational resources'. Online. https://tinyurl.com/yk225t8b (accessed 6 January 2020).

European Commission (2015) Education and Training Monitor 2015. Luxembourg: Publications Office of the European Union.

European Parliament (2000) 'Lisbon European Council 23 and 24 March 2000: Presidency conclusions'. Online. www.europarl.europa.eu/summits/lis1_en.htm (accessed 5 February 2020).

European Parliament and Council of the European Union (2006) 'Recommendation of the European Parliament and of the Council of 18 December 2006 on key competences for lifelong learning'. Official Journal of the European Union, L394, 49, 10-18. Online. https://tinyurl.com/yh7hc7rm (accessed 6 January 2020).

Fend, H. (1980) Theorie der Schule. Munich: Urban und Schwarzenberg.

Fend, H. (2006) Neue Theorie der Schule: Einführung in das Verstehen von Bildungssystemen. Wiesbaden: VS Verlag für Sozialwissenschaften.

Fichten, W. (1993) Unterricht aus Schülersicht: Die Schülerwahrnehmung von Unterricht als erziehungswissenschaftlicher Gegenstand und ihre Verarbeitung im Unterricht. Frankfurt am Main: Peter Lang.

Fraillon, J., Ainley, J., Schulz, W., Friedman, T. and Gebhardt, E. (2014) Preparing for Life in a Digital Age: The IEA International Computer and Information Literacy Study international report. Cham: Springer. Online. https://tinyurl.com/yfh7wxfn (accessed 6 January 2020).

Haydn, T. (2013) 'What does it mean "to be good at ICT" as a history teacher?'. In Haydn, T. (ed.) Using New Technologies to Enhance Teaching and Learning in History. London: Routledge, 6-28.

Hesse, F.W. (2004) 'E-Learning als Chance für eine neue Lernkultur'. In Aeberli, C. (ed.) Lehrmittel neu diskutiert: Ergebnisse des 1. Schweizer Lehrmittelsymposiums vom 29. und 30. Januar 2004 auf dem Wolfsberg in Ermatingen TG. Zürich: Lehrmittelverlag des Kantons Zürich, 41-51.

Hodel, J. (2013) Verkürzen und Verknüpfen: Geschichte als Netz narrative Fragmente: Wie Jugendliche digitale Netzmedien für die Erstellung von Referaten im Geschichtsunterricht verwenden. Bern: Hep. 
Husbands, C. (1996) What is History Teaching? Language, ideas and meaning in learning about the past. Buckingham: Open University Press.

Ito, M., Gutiérrez, K., Livingstone, S., Penuel, B., Rhodes, J., Salen, K., Schor, J., Sefton-Green, J. and Watkins, S.C. (2013) Connected Learning: An agenda for research and design: A research synthesis report of the Connected Learning Research Network. Irvine, CA: Digital Media and Learning Research Hub.

Jenkins, H., Clinton, K., Purushotma, R., Robison, A.J. and Weigel, M. (2006) Confronting the Challenges of Participatory Culture: Media education for the 21st century. Chicago: MacArthur Foundation.

Jones-Nerzic, R. (2013) 'Documentary film making in the history classroom'. In Haydn, T. (ed.) Using New Technologies to Enhance Teaching and Learning in History. London: Routledge, 83-94.

Kazamias, A. (2009) 'On educational knowledge - a neglected theme in comparative education'. In Cowen, R. and Kazamias, A.M. (eds) International Handbook of Comparative Education. Dordrecht: Springer, 803-12.

Kelly, T.M. (2013) Teaching History in the Digital Age. Ann Arbor: University of Michigan Press.

Kerber, U. (2015) 'WebQuests und Web Inquiry Projects zur Förderung von Medienkompetenz in der Geschichtsdidaktik'. In Buchberger, W., Kühberger, C. and Stuhlberger, C. (eds) Nutzung digitaler Medien im Geschichtsunterricht. Innsbruck: StudienVerlag, 81-97.

KMK (Kultusministerkonferenz) (2016) Bildung in der digitalen Welt: Strategie der Kultusministerkonferenz. Berlin: Kultusministerkonferenz. Online. https://tinyurl.com/yxfxj6ts (accessed 6 January 2020).

Körber, A. (2008) 'Kompetenzorientiertes Geschichtslernen in virtuellen Räumen?'. In Danker, U. and Schwabe, A. (eds) Historisches Lernen im Internet: Geschichtsdidaktik und Neue Medien. Schwalbach am Taunus: Wochenschau Verlag, 42-59.

Körber, A., Schreiber, W. and Schöner, A. (eds) (2007) Kompetenzen historischen Denkens: Ein Strukturmodell als Beitrag zur Kompetenzorientierung in der Geschichtsdidaktik. Neuried: Ars Una.

Kubetzky, T. (2010) 'Computerspiele als Vermittlungsinstanzen von Geschichte? Geschichtsbilder in Aufbausimulationsspielen am Beispiel von Civilization III'. In Schwarz, A. (ed.) "Wollten Sie auch immer schon einmal pestverseuchte Kühe auf ihre Gegner werfen?": Eine fachwissenschaftliche Annäherung an Geschichte im Computerspiel. Münster: Lit, 63-94.

Kühberger, C. (2015) 'Dokumentierte Dialogizität - Digitales historisches Lernen als gesellschaftliche Partizipation'. In Buchberger, W., Kühberger, C. and Stuhlberger, C. (eds) Nutzung digitaler Medien im Geschichtsunterricht. Innsbruck: StudienVerlag, 37-52.

Lang-Wojtasik, G. (2008) Schule in der Weltgesellschaft: Herausforderungen und Perspektiven einer Schultheorie jenseits der Moderne. Weinheim: Juventa.

Lawn, M. and Grek, S. (2012) Europeanizing Education: Governing a new policy space. Oxford: Symposium Books.

Leuze, K., Brand, T., Jakobi, A.P., Martens, K., Nagel, A., Rusconi, A. and Weymann, A. (2008) Analysing the Two-Level Game: International and national determinants of change in education policy making (TranState Working Paper 72). Bremen: University of Bremen. Online. https://tinyurl.com/yffyutsn (accessed 6 January 2020).

Loveless, A. and Williamson, B. (2013) Learning Identities in a Digital Age: Rethinking creativity, education and technology. London: Routledge.

Lyndon, D. (2013) 'Using blogs and podcasts in the history classroom'. In Haydn, T. (ed.) Using New Technologies to Enhance Teaching and Learning in History. London: Routledge, 73-82.

Martens, K. and Wolf, K.D. (2006) 'Paradoxien der Neuen Staatsräson: Die Internationalisierung der Bildungspolitik in der EU und der OECD'. Zeitschrift für Internationale Beziehungen, $13(2), 145-76$.

Martens, M. (2010) Implizites Wissen und kompetentes Handeln: Die empirische Rekonstruktion von Kompetenzen historischen Verstehens im Umgang mit Darstellungen von Geschichte. Göttingen: Vandenhoeck und Ruprecht.

Marzinka, B. (2015) 'Weblogs in der historisch-politischen Bildung'. In Demantowsky, M. and Pallaske, C. (eds) Geschichte lernen im digitalen Wandel. Berlin: De Gruyter Oldenbourg, 91-104.

Ministeriet for børn, undervisning og liegestilling (2010) Historie A - Stx: Vejledning/Råd og vink. Kontoret for Gymnasiale Uddannelser.

Moos, L. and Kofod, K.K. (2012) 'Denmark: Bildung in a competitive state?'. In Louis, K.S. and Van Velzen, B. (eds) Educational Policy in an International Context: Political culture and its effects. New York: Palgrave Macmillan, 63-71. 
Moutsios, S. (2007) 'The European Union and its education policy'. In Kotthoff, H.-G. and Moutsios, S. (eds) Education Policies in Europe: Economy, citizenship, diversity. Münster: Waxmann, 15-25.

Niedersächsisches Kultusministerium (2011) Kerncurriculum für das Gymnasium - gymnasiale Oberstufe, die Gesamtschule - gymnasiale Oberstufe, das Berufliche Gymnasium, das Abendgymnasium, das Kolleg: Geschichte. Hannover: Niedersächsisches Kultusministerium. Online. https://tinyurl.com/yzdx959n (accessed 6 January 2020).

Pallaske, C. (2015) 'Die Vermessung der (digitalen) Welt: Geschichtslernen mit digitalen Medien'. In Demantowsky, M. and Pallaske, C. (eds) Geschichte lernen im digitalen Wandel. Berlin: De Gruyter Oldenbourg, 135-47.

Pallaske, C. (2017) 'Kollaboratives Schreiben'. In Bernsen, D. and Kerber, U. (eds) Praxishandbuch Historisches Lernen und Medienbildung im digitalen Zeitalter. Opladen: Verlag Barbara Budrich, 304-12.

Parreira do Amaral, M. (2006) The Influence of Transnational Organizations on National Education Systems. Frankfurt am Main: Peter Lang.

P21 (Partnership for 21st Century Skills) (2007) The Intellectual and Policy Foundations of the 21st Century Skills Framework.

Rizvi, F. and Lingard, B. (2009) 'The OECD and global shifts in education policy'. In Cowen, R. and Kazamias, A.M. (eds) International Handbook of Comparative Education. Dordrecht: Springer, 437-53.

Rizvi, F. and Lingard, B. (2010) Globalizing Education Policy. London: Routledge.

Rüsen, J. (2008) Historisches Lernen: Grundlagen und Paradigmen. Schwalbach am Taunus: Wochenschau Verlag.

Seixas, P. and Ercikan, K. (2015) 'Introduction: The new shape of history assessments'. In Ercikan, K. and Seixas, P. (eds) New Directions in Assessing Historical Thinking. New York: Routledge, 1-13.

Seixas, P. and Morton, T. (2013) The Big Six: Historical thinking concepts. Toronto: Nelson Education.

Selwyn, N. (2013) Education in a Digital World: Global perspectives on technology and education. New York: Routledge.

Selwyn, N. (2014) Distrusting Educational Technology: Critical questions for changing times. New York: Routledge.

Spahn, T. (2017) 'Historisches Lernen mit WebQuests'. In Bernsen, D. and Kerber, U. (eds) Praxishandbuch Historisches Lernen und Medienbildung im digitalen Zeitalter. Opladen: Verlag Barbara Budrich, 355-62.

Theobald, U. (2013) 'Die Auswirkungen der globalen Modernisierung auf die gesellschaftliche Rolle nationaler Bildungssysteme'. In Amos, K., Schmid, J., Schrader, J. and Thiel, A. (eds) Kultur - Ökonomie - Globalisierung: Eine Erkundung von Rekalibrierungsprozessen in der Bildungspolitik. Baden-Baden: Nomos, 43-61.

Thomas, D. and Brown, J.S. (2011) A New Culture of Learning: Cultivating the imagination for a world of constant change. Lexington, KY: CreateSpace.

Thüringer Ministerium für Bildung, Wissenschaft und Kultur (2011) Lehrplan für den Erwerb der allgemeinen Hochschulreife: Geschichte. Erfurt: Thüringer Ministerium für Bildung, Wissenschaft und Kultur.

Tribukait, M. (2018) 'Zwischen digitalen Angeboten und geschichtsdidaktischen Anforderungen: Zur Medialität des Geschichtsunterrichts'. Zeitschrift für Geschichtsdidaktik, 17, 135-49.

Tribukait, M., Baier, K., Grzempa, H., Loukovitou, A., Sijakovic, R., Tettschlag, N. and Vuka, D. (2017) Digital Learning in European Education Policies and History Curricula. Braunschweig: Georg Eckert Institute for International Textbook Research.

Undervisningsministeriet (2013) 'Bekendtgørelse om uddannelsen til studentereksamen (BEK nr 776 af 26/06/2013): Bilag 27: Historie A - stx, juni 2013'. Online. www.retsinformation.dk/Forms/R0710.aspx?id=152507\#Bil27 (accessed 5 February 2020).

Van Drie, J. and Van Boxtel, C. (2008) 'Historical reasoning: Towards a framework for analyzing students' reasoning about the past'. Educational Psychology Review, 20, 87-110.

Von Borries, B. (1995) Das Geschichtsbewusstsein Jugendlicher: Erste repräsentative Untersuchung über Vergangenheitsdeutungen, Gegenwartswahrnehmungen und Zukunftserwartungen von Schülerinnen und Schülern in Ost- und Westdeutschland. Weinheim: Juventa.

Von Borries, B., Fischer, C., Leutner-Ramme, S. and Meyer-Hamme, J. (2005) Schulbuchverständnis, Richtlinienbenutzung und Reflexionsprozesse im Geschichtsunterricht: Eine qualitativquantitative Schüler- und Lehrerbefragung im deutschsprachigen Bildungswesen 2002. Neuried: Ars Una.

Wineburg, S. (2001) Historical Thinking and Other Unnatural Acts: Charting the future of teaching the past. Philadelphia: Temple University Press. 